\title{
A (IN)EFICÁCIA SOCIAL DOS DIREITOS E GARANTIAS FUNDAMENTAIS DAS PESSOAS EM SITUAÇÃO DE RUA
}

\author{
Rayane Aquino de Souza* \\ GustaVo СоTOMACCI**
}

\section{RESUMO}

O objetivo do presente artigo consiste em analisar a eficácia social dos direitos e garantias fundamentais previstos em nosso ordenamento jurídico em relação às pessoas em situação de rua. Para isso, foi definido o conceito de eficácia, como também explanado sobre as normas constitucionais garantidoras de direitos, demonstrando assim, a importância e o valor dos direitos e garantias fundamentais para todos da sociedade. Contudo, cuidou de adentrar especialmente na realidade social das pessoas em situação de rua para identificar quem são, qual tem sido a atuação do Estado e quais são as normas específicas para efetivação de princípios fundamentais para assegurar a este grupo de pessoas às prerrogativas pertinentes a elas e qualquer ser humano. Assim, além de expor este contexto social à luz das normas jurídicas e doutrinas, foram apresentados dados obtidos em últimas pesquisas nacionais realizadas pelo IPEA e pelo MDS. Para tanto, também foi necessário adentrar especificamente nas políticas públicas como matéria fundamental para a concretização dos direitos fundamentais expostos. Após as análises feitas foi possível verificar falhas evidentes na aplicação dos direitos fundamentais ao que diz respeito à população em situação de rua, bem como o possível enquadramento ao Estado de Coisas Inconstitucional.

Palavras-chave: Direitos Fundamentais. Ineficácia social. Políticas Públicas. Moradores de rua.

\section{THE (IN)EFFICIENCY OF SOCIAL RIGHTS AND BASIC GUARANTEES FOR PEOPLE IN STREET SITUATION}

\section{ABSTRACT}

The objective of this article is to analyze the social effectiveness of the fundamental rights and guarantees provided in our legal system in relation to people in street situations. To this end, the concept of effectiveness has been defined, as well as explained about the constitutional norms guaranteeing rights, thus demonstrating the importance and value of fundamental rights and guarantees for all in society. However, it has taken care of entering especially in the social reality of people in street situation to identify who they are, what has been the action of the State and what are the specific norms for

* Rayane Aquino de Souza, advogada, bacharel em Direito pela Universidade Metodista de São Paulo - UMESP. E-mail: rayaneaquino.ds@gmail.com.

** Gustavo Cotomacci, professor mestre, orientador no Curso de Direito na Universidade Metodista de São Paulo - UMESP. E-mail: gustavo.cotomacci@metodista.br. 
the realization of fundamental principles to assure to this group of people the prerogatives pertinent to them and any human being. Thus, besides exposing this social context in the light of legal norms and doctrines, data obtained from the latest national research carried out by the IPEA and the MDS have been presented. For this, it was also necessary to specifically enter into public policies as a fundamental matter for the realization of the fundamental rights exposed. After the analyses made it was possible to verify evident failures in the application of fundamental rights to what concerns the street population, as well as the possible framing of the State of Unconstitutional Things.

Key words: Fundamental Rights. Social ineffectiveness. Public policy. Homeless.

\section{INTRODUÇÃO}

O presente artigo visa compreender os direitos e garantias fundamentais como normas essenciais à existência de todos, independente da realidade em que se encontram. Será analisado se de fato essas normas produzem efetividade, alcançando determinados grupos de pessoas, especificamente, irá abordar as questões relativas às pessoas em situação de rua, que tratam justamente de indivíduos que demonstram a existência da ineficácia social de certas previsões legais que temos como garantias fundamentais em nossa Constituição Federal de 1988.

Além desta investigação inicial, no qual serão esclarecidos quais são esses direitos fundamentais e o problema da eficácia destas garantias em relação às pessoas em situação de rua, o presente estudo tem como finalidade também em levantar questões inerentes às políticas públicas, ampliando e demonstrando como o Estado tem agido diante deste fato.

Portanto, é importante frisar que a motivação principal de todo conteúdo a ser exposto é o próprio ser humano, mais do que apresentar leis e doutrinas significativas no mundo jurídico, precisamos atestar se isso vai além do papel escrito, e se não for, devemos buscar medidas cabíveis para efetivá-los. No entanto, o objeto a ser analisado é a vida digna da pessoa humana acima de tudo e para todos.

O escopo deste trabalho é que desperte e restaure a essência do Direito em meio a este contexto específico, pois o Direito está totalmente envolvido com a vida de cada pessoa. Sendo assim, a temática é ideal para quem ainda não se conformou e se recusa a ser indiferente com a realidade vivenciada. Mas, tem esperança e insiste em fazer valer os dispositivos legais a fim de que as garantias previstas ecoem na vida de todos.

\section{DA EFICÁCIA DAS NORMAS CONSTITUCIONAIS}

A Constituição é a lei essencial e fundamental para conduzir todo o contexto social e político do país. O seu alvo é fazer valer cada princípio norteador por intermédio das normas que devem propor estratégias e parâmetros para que o Estado cresça e evolua, garantindo a melhoria em todos os aspectos para todos os indivíduos.

No Brasil, a Constituição Federal vigente é a sétima da história do país e foi promulgada em 1988, sendo esta a lei suprema que decorre "o sistema federativo do Estado; o voto 
direto, secreto, universal e periódico; a separação dos Poderes; e os direitos e as garantias individuais" (BRASIL. Governo do Brasil, 2019).

Como podemos observar, a Constituição exala certa relevância em detrimento as outras leis do nosso ordenamento jurídico, Regina Ferrari (2001, p. 30) enfatiza que "[...] a norma suprema, mais importante de um sistema normativo estatal é a sua Constituição, sendo o fundamento de validade dessa mesma ordem jurídica", para tanto é necessário zelo e seriedade ao tratar da Lei Maior, tendo em vista que todas as condutas positivadas pelo direito deverão ser correspondentes a ela.

Contudo, é notável a força normativa da Constituição Federal, todas as outras normas precisam ser compatíveis sob pena de serem declaradas inconstitucionais, tornando-se sem efeito.

Em suma, ao pensar na Constituição Federal temos o coração do ordenamento jurídico. É o conjunto de princípios e garantias que deverão condicionar todas as outras normas tendo em vista que todas suas previsões dizem respeito a aspectos fundamentais para a vida em sociedade.

\section{A DELIMITAÇÃO CONCEITUAL DE EFICÁCIA}

O termo "eficácia" possui grande relevância ao tratarmos das normas constitucionais, pois diz respeito à finalidade da norma, ou seja, traz a existência, fazendo com que a Lei escrita ganhe forma no mundo social.

Para Ingo Wolfgang Sarlet (2009, p. 235), “o termo 'eficácia' engloba indubitavelmente uma múltipla gama de aspectos passíveis de problematização e análise [...]", tanto é que existem classificações doutrinárias especialmente para tratar deste item de extrema importância para as normas constitucionais.

Nesse sentido, o doutrinador Jose Afonso da Silva (1999) conceitua eficácia como a capacidade de atingir objetivos previamente fixados como metas pelo legislador. Sendo assim, a eficácia é o que faz valer os preceitos legais, é o que promove a real finalidade das normas perante a sociedade. Com isso em mente, Luís Roberto Barroso esclarece que a eficácia é a competência que revestem as normas constitucionais para produzir os efeitos arquitetados em sua criação:

A eficácia dos atos jurídicos consiste na sua aptidão para a produção de efeitos, para a irradiação das consequências que lhe são próprias. Eficaz é o ato idôneo para atingir a finalidade para a qual foi gerado. Tratando-se de uma norma, a eficácia jurídica designa a qualidade de produzir, em maior ou menor graus, os seus efeitos típicos, "ao regular, desde logo, as situações, relações e comportamentos nela indicados; nesse sentido, a eficácia diz respeito à aplicabilidade, exigibilidade ou executoriedade da norma (BARROSO, 2000, p. 83).

Embora haja diversos aspectos relacionados ao conceito de eficácia, a doutrina converge em dois pontos centrais para um entendimento amplo sobre o tema, que se trata da eficácia jurídica e eficácia social das normas constitucionais, que serão abordados detalhadamente no item posterior. 


\section{A EFICÁCIA JURÍDICA E SOCIAL}

A eficácia jurídica se baseia na capacidade a qual a norma produz em alcançar a sua finalidade, relacionando-se com a possibilidade de ser executado. Ingo Sarlet (2009, p. 238) leciona que "[...] a eficácia jurídica consiste justamente na possibilidade de aplicação da norma aos casos concretos, com a consequente geração dos efeitos jurídicos que lhe são inerentes $[\ldots]^{\prime \prime}$.

O ideal é que a norma constitucional seja juridicamente eficaz, quanto sua aplicabilidade e que alcance a sociedade, produzindo de fato a finalidade pretendida no meio social, porém, nem todas as normas possuem eficácia jurídica e social, algumas são dotadas apenas de efeitos no sistema jurídico. Nesse sentido, José Afonso da Silva (1999, p. 66) discorre que "uma norma pode ter eficácia jurídica sem ser socialmente eficaz, isto é, pode gerar certos efeitos jurídicos, como, por exemplo, o de revogar normas anteriores, e não ser efetivamente cumprida no plano social".

Posto isso, trataremos do conceito de eficácia social. Ela é a realização do que foi planejado pela norma no âmbito do contexto social, se trata de sua efetivação no mundo dos fatos. José Afonso da Silva (1999, p. 65) diz que "a eficácia social designa uma efetiva conduta acorde com a prevista pela norma; refere-se ao fato de que a norma é realmente obedecida e aplicada [...]".

Para Luís Roberto Barroso (2000), a eficácia social, traz a noção de efetividade, visto que ainda assim, este termo está relacionado ao impacto que a norma produz no mundo dos fatos. De acordo com o doutrinador, a efetividade significa, portanto, a realização do Direito, o desempenho concreto de sua função social.

Sendo assim, ocorre a eficácia social quando aquilo que foi projetado em lei acontece de forma como esperada diante da sociedade, ou seja, além dos efeitos jurídicos atingidos, para a eficácia social ou efetividade ocorrer, deve haver a aceitação na vida social.

\section{A EFICÁCIA DAS NORMAS CONSTITUCIONAL}

Outro ponto importante a ser analisado diz respeito à aplicabilidade constitucional, sendo que os dois institutos caminham juntos. Pode-se dizer que a aplicabilidade é o "caminho" que a norma percorre para produzir os seus efeitos, ou seja, está diretamente ligada ao momento da execução. Como vimos as normas constitucionais já são eivadas de eficácia por força normativa de sua natureza, para tanto, é necessário verificar como se dá a sua efetiva aplicação. José Afonso da Silva (1999) afirma que todas as normas constitucionais possuem eficácia, porém nem todas manifestam-se em sua plenitude, dependendo de uma normação jurídica ordinária ou complementar executória. Ou seja, para produzir de fato os seus efeitos, será necessário regulamentação posterior.

Quando pensamos na estrutura de uma norma constitucional, existem elementos que precisam estar presentes para que haja o sucesso da norma, tais como a validade, a vigência, a eficácia e a aplicabilidade. A validade está relacionada à sua elaboração, se de fato a norma foi elaborada pelas condições formais corretamente previstas em lei. Já a vigência se trata da exigibilidade da norma, é o que a faz existir no mundo do direito e a sua obrigatoriedade no mundo dos fatos. Relaciona-se com a promulgação e a publicação da norma. Assim, afirma José Afonso da Silva:

\footnotetext{
Vigência (do verbo viger, do latim vigere) é, no sentido indicado, a qua-
} 
lidade da norma que a faz existir juridicamente e a torna de observância obrigatória, isto é, que a faz exigível, sob certas condições. Vigência, pois, é o modo específico da existência da norma jurídica. Vigência não se confunde com eficácia, como veremos mais embaixo; mas para que a eficácia se verifique é necessário que a norma comece a vigorar. A vigência é condição de efetivação da eficácia [...] (SILVA J, 1999, p. 52).

Desse modo, por mais que não seja tão simples analisar e distinguir as normas constitucionais mediante sua eficácia, esse é um meio que visa facilitar a compreensão do alcance das normas, sendo possível visualizar aquelas que necessitam de cuidado legislativo, e assim, buscar formas para que de fato todas possam produzir a eficácia pertinente.

\section{DOS DIREITOS E GARANTIAS FUNDAMENTAIS}

Os direitos fundamentais tratam de prerrogativas essenciais para conceber a toda pessoa condições de viverem dignamente. A relevância de tais direitos, é de se esperar que a sua previsão seja constitucional, a doutrinadora Regina Maria Nery Ferrari esclarece:

A afirmação dos direitos fundamentais, como essência do que se denomina de dignidade humana, representa o avanço do direito constitucional na atualidade, quando se aceita que a Constituição é a norma suprema do ordenamento jurídico e que os valores mais importantes da existência do homem devem estar por ela resguardados, em virtude de sua força normativa ser vinculativa para o Estado e para toda a sociedade (FERRARI, 2011, p.530).

Em relação à Constituição Federal do Brasil de 1988, há de notar as suas peculiaridades perante as anteriores, ainda mais ao que diz respeito aos direitos e garantias fundamentais ali expostos, Manoel Gonçalves Ferreira Filho (2011) salienta que a Declaração vigente em nossa Constituição é a mais abrangente e extensa de todas as anteriores, incluindo as liberdades públicas clássicas e trazendo ênfase até aos direitos de matéria penal.

Para tanto, é importante esclarecer sobre as liberdades públicas. O doutrinador Manoel Gonçalves Ferreira Filho explana a respeito deste tema em uma de suas obras, afirma que "são poderes de agir reconhecidos e protegidos pela ordem jurídica a todos os seres humanos" (2012, p. 46). Portanto, constitui o núcleo dos direitos fundamentais.

Além do mais, há outros aspectos que a diferencia das demais constituições que já vigeram no Brasil, tanto em sua estrutura quanto na colocação dos direitos e garantias fundamentais que são enumerados no Título II do texto constitucional (BRASIL, 1988).

Sobre os direitos sociais, o doutrinador ainda faz uma breve síntese de sua estruturação na Constituição Federal, bem como cita o direito à moradia como parte deste núcleo, acrescentado pela Emenda Constitucional em 2000. Assim, denota Manoel Gonçalves Ferreira Filho:

A Constituição enuncia, no art. $6^{\circ}$, alguns direitos sociais, que são também direitos fundamentais: a educação, o trabalho, o lazer, a segurança 
e previdência social, a proteção à maternidade e à infância, e assistência aos desamparados, aos quais a Emenda Constitucional n.26/2000 acrescentou o direito à moradia (FERREIRA FILHO, 2012, p. 130).

Sendo assim, os direitos mencionados que compõe os direitos sociais são também considerados Direitos Fundamentais, garantias para promover uma vida digna a todo e qualquer ser humano. Nesse sentido, Manoel Gonçalves Ferreira Filho (2012) considera que, os direitos sociais são alcançados pelas cláusulas pétreas mesmo não sendo parte do rol dos "direitos e garantias individuais" que são os considerados os direitos de liberdades.

Mediante todo exposto é evidente que a Constituição Federal brasileira de 1988 trata os direitos fundamentais com bastante cautela. Desse modo, neste momento é importante mencionar o que a Constituição Federal possui um rol inspirador sobre os direitos fundamentais. Portanto, o presente artigo irá limitar quanto aos direitos citados, apenas se referindo àqueles que são drasticamente prejudicados em relação ao tema central proposto no decorrer dos próximos capítulos.

\section{A EFICÁCIA DOS DIREITOS FUNDAMENTAIS}

Uma vez já esclarecido sobre a eficácia das normas constitucionais e os principais aspectos dos direitos e garantias fundamentais, veremos que a própria Constituição prevê como se dá a aplicação desses direitos.

O artigo $5^{\circ}$, $\S 1^{\circ}$, da Constituição Federal de 1988, enuncia que "as normas definidoras dos direitos e garantias fundamentais têm aplicação imediata", ou seja, os resultados que tais normas desejam alcançar dependem exclusivamente de seu enunciado. A partir disso, presume-se a eficácia dessas garantias.

Não há dúvidas quanto à previsão legal da aplicabilidade dos direitos fundamentais, pois o próprio texto Constitucional dispõe sobre a aplicabilidade imediata das normas de natureza fundamental.

A eficácia desses direitos é inegociável, o imediatismo que a Constituição prevê enseja a ideia de importância e primazia que estas normas possuem ao serem concretizadas, revelando que acima de tudo precisam ser respeitadas e cumpridas.

Assim sendo, o texto constitucional não permite restar dúvidas acerca da aplicabilidade das normas que preveem os direitos e garantias fundamentais, porém, é certo que existem os efeitos jurídicos e sociais.

Há ainda questionamentos por ser gritante a inefetividade desses direitos de forma plena, sendo então, o motivo de análise no que diz respeito à eficácia social que será feita a seguir, especialmente no que diz respeito às pessoas em situação de rua.

\section{DAS PESSOAS EM SITUAÇÃO DE RUA}

A princípio, será explanado sobre a contextualização e caracterização das pessoas em situação de rua, expondo as principais particularidades dessa classe social. Após, será apresentada as últimas estimativas relacionadas à população de rua, sendo possível identificar o contexto em que este instituto está inserido no Brasil. Em decorrência, tratará também como essas pessoas estão situadas no ordenamento jurídico brasileiro, e visa demonstrar 


\title{
A (IN)EFICÁCIA SOCIAL DOS DIREITOS E GARANTIAS FUNDAMENTAIS DAS PESSOAS EM SITUAÇÃO DE RUA
}

sua relevância como titulares de direitos como qualquer outro cidadão, possibilitando a visualização deste contexto social frente aos direitos e garantias fundamentais na atualidade.

\section{CONTEXTUALIZAÇÃO E CARACTERIZAÇÃO DAS PESSOAS EM SITUAÇÃO DE RUA}

Em 23 de dezembro de 2009 foi instituída a política nacional para a população em situação de rua e seu Comitê Intersetorial de Acompanhamento e Monitoramento, e dá outras providências conforme disponibilizado no diário oficial da União - Decreto 7.053/2009 (BRASIL, 2009).

A definição de pessoas em situação de rua encontra-se expressamente definida no parágrafo único do artigo $1^{\circ}$ do Decreto 7.053 de 2009:

\begin{abstract}
Considera-se população em situação de rua um grupo populacional heterogêneo que possui em comum a pobreza extrema, os vínculos familiares interrompidos ou fragilizados e a inexistência de moradia convencional regular, e que utiliza de logradouros públicos e as áreas degradadas como espaço de moradia e de sustento, de forma temporária ou permanente, bem como as unidades de acolhimento para pernoite temporário ou como moradia provisória (BRASIL, 2009).
\end{abstract}

Portanto, é possível notar facilmente as pessoas que estão submetidas à situação de rua. As características previstas apenas formalizam o que é extremamente visível ao se deparar com indivíduos neste contexto.

Sendo assim, uma das principais evidências é o fato dessas pessoas não possuírem residência fixa amparada por paredes e teto, mas, viverem em áreas consideradas desapropriadas para habitação. O doutrinador Valerio de Oliveira Mazzuoli explica que a "situação de rua" é entendida como a falta de habitação convencional regular de determinada pessoa, tendo como morada vias ou logradores públicos, sem condições mínimas de higiene, como também em centros de acolhimento ou abrigos de emergência, públicos ou privados (MAZZUOLI, 2018). Neste sentindo, Maria Lúcia Lopes da Silva consente:

A população em situação de rua pode ser compreendida como grupo de
indivíduos diversos, que partilham a pobreza extrema, e muitas vezes,
com os vínculos familiares interrompidos, fragilizados e que por não pos-
suir uma moradia fixa, habitam transitoriamente diversos logradouros
públicos (ruas, praças, jardins, canteiros, marquises e baixios de viadu-
tos), as áreas degradadas (dos prédios abandonados, ruínas, cemitérios e
carcaças de veículos) podendo utilizar albergues ou moradias provisórias
para pernoitar (SILVA M, 2009 apud VIEIRA, et al, 2018, p.203).

No mais, outro aspecto importante para caracterização dessas pessoas está relacionado ao fato de que a população em situação de rua se trata de um grupo heterogêneo, conforme o decreto. Portanto, se trata de um grupo diversificado de pessoas, com diferentes características e motivações, podendo ser do recém-nascido ao mais idoso.

Para elucidar este entendimento, vale mencionar o conceito trazido pelo Conselho para Prevenir e Eliminar a Discriminação na Cidade do México (CONSEJO), que se trata de 
uma das medidas tomadas pelo México para "a promoção do desenvolvimento dos grupos mais vulneráveis a exclusão" (BRASIL. Fundação, 2006). Assim conceitua o CONSEJO:

A população de rua é um grupo social diversificado, composto por meninas, meninos, jovens, mulheres, famílias, idosos, pessoas com deficiência e outros com vários problemas de saúde e vícios. Em geral, o termo refere-se a qualquer pessoa ou grupo de pessoas com ou sem relação entre si, que subsistem na rua ou no espaço público usando recursos próprios e precários para satisfazer suas necessidades básicas. O termo "população de rua" é usado para nomear "aqueles que compartilham a mesma rede social de sobrevivência e juntos desenvolveram uma cultura de rua (CONSEJO, 2016 apud VIEIRA et al., 2018, p.33).

Embora haja uma relação entre essas pessoas devido a contextualização que as abrangem, o caráter heterogêneo que estas possuem também pode ser considerado para analisar os motivos que as levam para realidade citada.

Muitas vezes, as pessoas em situação de rua são visualizadas de uma forma generalizada, o que não pode ocorrer sendo que cada indivíduo possui suas particularidades, isto é o que aborda Tereza Rodrigues Vieira e Vanessa Carvalho dos Santos:

Assim, ser desabrigado não é apenas dormir na rua. As pessoas forçadas a viver em moradias temporárias, insalubres ou precárias também são consideradas desabrigadas, dependendo da ótica do observador. As causas são diversas e dependem de como a pessoa enfrenta a situação para superá-la. Os motivos apresentados são o desemprego, a pobreza, as migrações, a velhice, os problemas de saúde, o rompimento de um relacionamento, a falta de moradia acessível para aluguel e venda, apoio insuficiente para pessoas que deixam a prisão, dentre outros.

Deste modo, não são apenas beberrões ou viciados, como são comumente reconhecidos, são seres humanos que passaram por circunstâncias difíceis e, muitas vezes não resolvidas, tendo como epílogo e sua única alternativa, a sobrevivência nas ruas (VIEIRA; SANTOS, 2018, p. 33-34).

À luz do exposto, cada um em sua individualidade precisa ser considerado quando tratamos das pessoas sem situação de rua. Como citado, irão existir aspectos sociais que estabelecem certo elo entre essas pessoas, porém, também existirão características a ser considerada em seu individual.

De longe, pode-se observar que as pessoas em situação de rua não estão exercendo todos os seus direitos básicos mínimos. Assim discorre Valerio de Oliveira Mazzuoli:

Pode-se dizer que a situação de rua discrimina e vulnerabiliza seres humanos já discriminados e vulnerabilizados por estarem excluídos da parcela economicamente ativa da sociedade, bem como também os marginaliza, em especial no contexto dos grandes centros urbanos, cujas condições de vida são ainda mais hostis. Trata-se de situação crítica pela qual passam grupos sociais excluídos em vários Estados, como reflexos globais a merecer a devida atenção das normas internas e internacionais de proteção dos direitos fundamentais e humanos (MAZZUOLI, 2018, p. 14). 
Em concordância com o citado, pode-se verificar que as pessoas em situação possuem direitos fundamentais e humanos claramente lesados, os motivos que caracterizam as pessoas nessa condição por si só já são dotados de ofensa à dignidade da pessoa humana.

Assim, as pessoas em situação de rua são seres humanos vulneráveis que necessitam de atenção especial para que independente de suas condições, ela também seja alcançada pelos direitos e garantias fundamentais inerentes a qualquer ser humano.

\section{ESTIMATIVAS DA POPULAÇÃO EM SITUAÇÃO DE RUA NO BRASIL}

No Brasil, não há um acompanhamento rígido no tocante as pessoas contextualizadas em situação de rua consoante a última estimativa oficial realizada pelo IPEA (Instituto de Pesquisa Econômica Aplicada), disponibilizado em outubro de 2016, que afirma que "o Brasil não conta com dados oficiais sobre a população em situação de rua" (BRASÍLIA, 2016, p.7).

Conforme citado, a última pesquisa foi executada pelo especialista em políticas públicas e gestão governamental na Diretoria de Estudos e Políticas do Estado, das Instituições e da Democracia (Diest) do Ipea, Marco Antonio Carvalho Natalino, que traz em suas considerações finais o seguinte resultado:

Estima-se que existam 101.854 pessoas em situação de rua no Brasil. Deste total, estima-se que dois quintos $(40,1 \%)$ habitem municípios com mais de 900 mil habitantes e mais de três quartos (77,02\%) habitem municípios de grande porte, com mais de 100 mil habitantes. Por sua vez, estima-se que nos 3.919 municípios com até 10 mil habitantes habitem 6.757 pessoas em situação de rua, (6,63\% do total). Ou seja, a população em situação de rua se concentra fortemente em municípios maiores (BRASÍLIA, 2016, p. 25).

Sobretudo, ao levar em consideração os aspectos históricos que tratam deste tema específico é possível verificar que existe certa falha em evidenciar a respeito da formação desta população, é o que explana os doutrinadores Nara Barczak, Tereza Vieira e Luís Fernando Argondizo:

Os registros históricos quanto a formação da população de em situação de rua no país, carecem de acervo específico, o que nos deixa a margem da interpretação das relações sociais ocorridas no mundo, filtrando seus reflexos em nossa sociedade. (BARCZACK; VIEIRA e ARGONDIZO, 2018, p. 83).

No entanto, eles explicam que conforme a evolução da sociedade, as questões inerentes ao contexto que se enquadram as pessoas em situação de rua foram se tornando cada vez mais manifestas mediante as divisões de classes. Para eles, foi na década de 1980 que este fato se tornou mais evidente, em decorrência de um sistema classificado em bases militares, onde a produção ficou centralizada nas mãos do governo, com certa restrição a dados sociais e econômicos que refletissem a realidade social e econômica do país (BARCZACK; VIEIRA e ARGONDIZO, 2018). 
Em seguida, ao analisar as possíveis causas do crescimento desta população podemos citar trecho de um artigo mencionado no estudo de Cristina Silva da Costa e Tereza Rodrigues Vieira que diz:

O crescente empobrecimento, a miséria e o desemprego a que está submetida grande parcela da população, ou seja, a perdas de papéis sociais relacionados à capacidade produtiva que o indivíduo exercia na sociedade capitalista, têm levado a esse movimento de ser, estar e morar na rua, obrigando muitos indivíduos a desenvolver novas estratégias de sobrevivência, frente às situações de violência, e a se adaptar às referências de vida social bem diferentes daquelas vividas anteriormente (GHIRARDI et. al., 2005 apud VIEIRA et al., 2018, p.203).

Em 2008, o Ministério do Desenvolvimento Social e Combate à fome (MDS) quebrou o silêncio quanto a esta realidade social. O MDS foi o único que se preocupou em analisar detalhes significativos deste segmento populacional, tanto é que os dados foram utilizados para recente matéria disponibilizada no portal do Senado em 27 de março de 2019 que versa sobre a invisibilidade nas estatísticas das pessoas em situação de rua. Com base nesses dados, o Senado ilustrou algumas informações relacionado as condições dessa classe, conforme veremos a seguir (BRASIL. Senado Federal, 2019).

Na época, foram registradas 31.922 pessoas maiores de 18 anos em situação de rua em 71 cidades brasileiras levantadas (BRASIL. MDS, 2009, p.229). Sendo assim, as porcentagens apresentadas nas figuras levam em consideração esse montante.

Como estamos lidando com os direitos fundamentais desta população, é imprescindível abordar sobre tais direitos. A primeira imagem trata do dia a dia do morador de rua:

\section{Dia a dia do morador de rua}

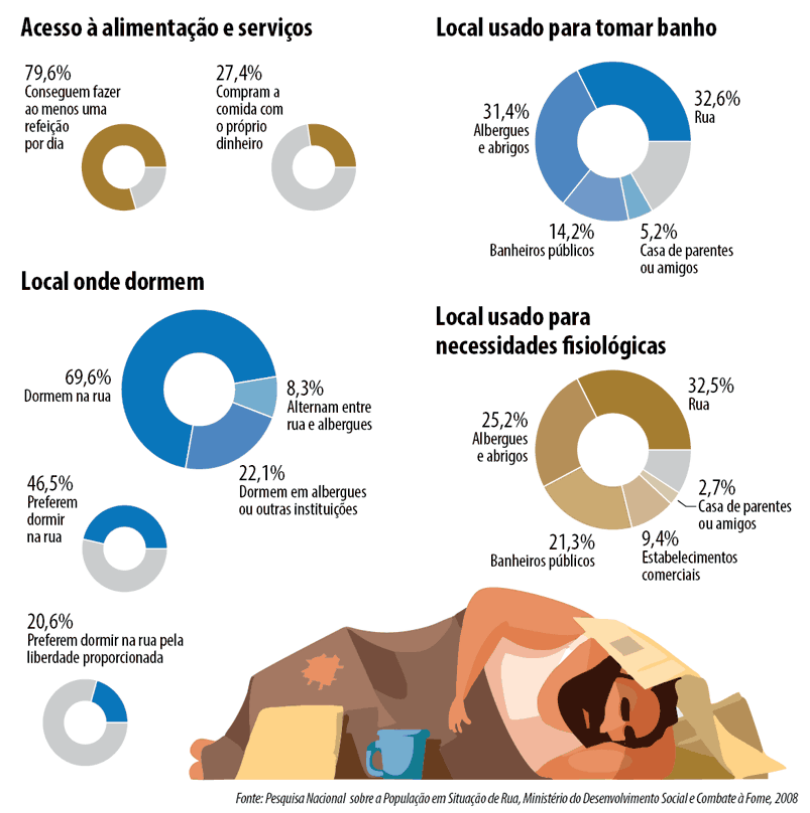

Figura 1 - Dia a dia do morador de rua

Fonte: BRASIL. Senado Federal (2019). 


\section{A (IN)EFICÁCIA SOCIAL DOS DIREITOS E GARANTIAS FUNDAMENTAIS DAS PESSOAS EM SITUAÇÃO DE RUA}

A imagem trata de aspectos essenciais ao homem, como a alimentação, locais para dormir, tomar banho e fazer suas necessidades fisiológicas. Conforme demonstrado, a maior parte das pessoas em situação de rua não adquire alimentação com o próprio dinheiro (apenas 27,4\%), enquanto o restante depende de outras formas para conseguir alimentos, em relação aos locais utilizados para dormir (preferência entre a rua ou albergues), $69,6 \%$ dorme efetivamente na rua, sendo que dentro dessa porcentagem 46,5\% dormem porque de fato preferem as ruas, e somente $22,1 \%$ optam por dormir em albergues. Para tomar banho, a porcentagem é acirrada 32,6\% utilizam as ruas e 31,4\% os albergues. Por fim, $32,5 \%$ utilizam as ruas para as suas necessidades fisiológicas, 25,2\% os albergues e abrigos, $21,3 \%$ os banheiros públicos e o restante, utilizam outros locais.

Nessa análise, é notório que boa parte das pessoas compreendidas nesta situação, passa o maior espaço de tempo nas ruas e realizam suas necessidades básicas nesse mesmo contexto.

Portanto, sob esta observação, pode-se assegurar que além de não obterem uma moradia digna, essas pessoas também estão sujeitas a condições precárias no tocante de suas necessidades mínimas, demonstrando a falta de integridade como ser humano, tendo a sua imagem totalmente exposta, pois uma vez que utilizam as vias públicas para tanto, qualquer um pode participar deste momento que em tese deveria ser particular.

Seguindo, a próxima figura demonstra algo muito importante referente à motivação que levam as pessoas à rua:

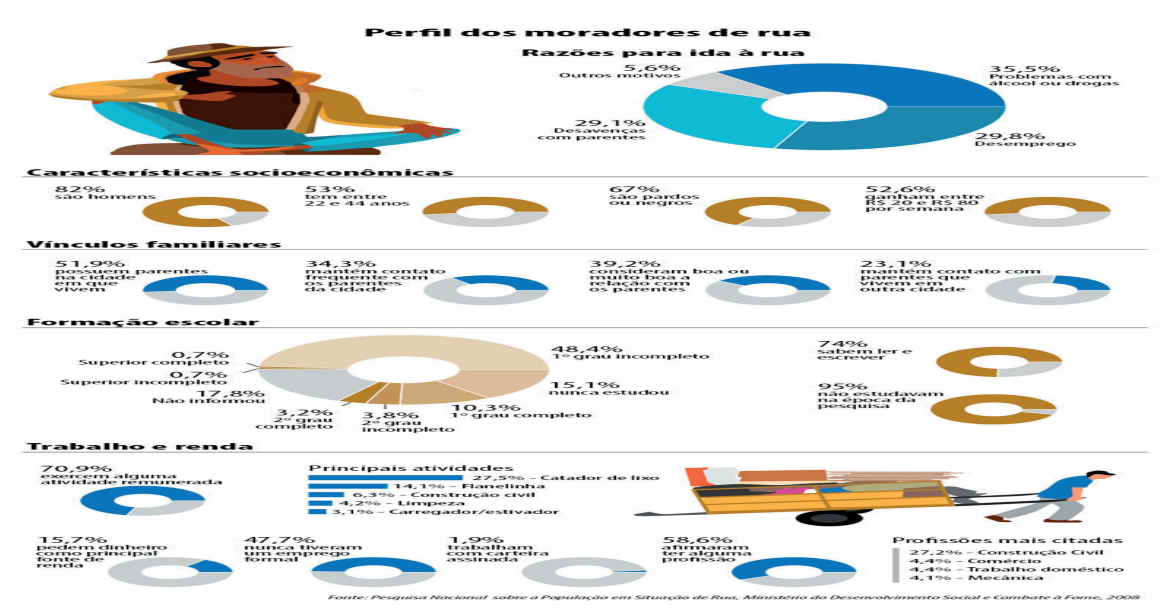

Figura 2 - Perfil dos moradores de rua

Fonte: BRASIL. Senado Federal (2019).

É possível verificar que em segundo lugar com 29,8\% das pessoas entrevistadas têm o desemprego como sua razão para se submeter à realidade de rua, embora as outras motivações também sejam apreciáveis para a atuação do Estado, quando vemos o desemprego em boa proporção como motivo, podemos considerar que há certa falha na aplicação em um dos direitos fundamentais, especialmente classificado nos direitos sociais da nossa Constituição.

Um dos direitos fundamentais sociais é o trabalho, infelizmente, os dados apontam que uma das motivações que faz com que as pessoas ingressem na jornada de rua é o de- 
semprego. Desta forma, pode-se dizer que a debilidade de apenas um dos direitos acaba resultando em mais: ausência de moradia, alimentação, segurança e os demais previstos.

Em complemento, a figura 3 também trata de uma estimativa que envolve outros direitos essenciais previstos em nossa Constituição Federal:

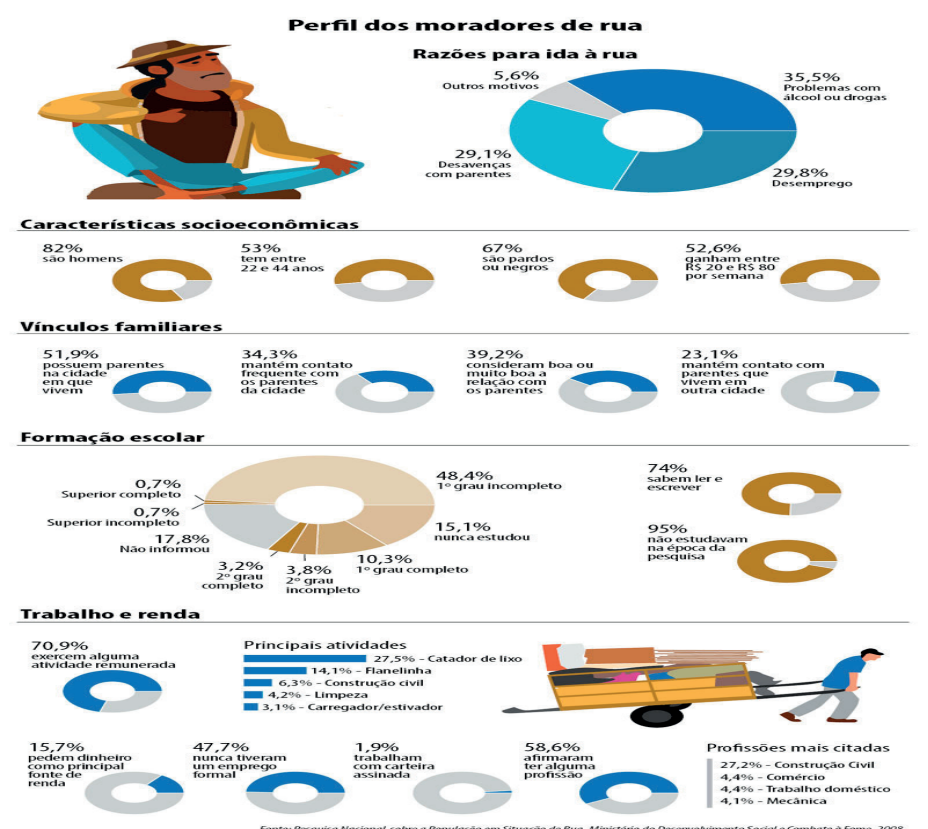

Figura 3 - Formação e Atividades dos moradores de rua

Fonte: BRASIL, Senado (2019).

Conforme a figura, a ilustração apresenta vasta falha em outro direito fundamental social: a educação (art. $6^{\circ}, \mathrm{CF}$ ). Chega a ser um tanto assustador, mas os dados apontam que $48,4 \%$ não tiveram o $1^{\circ}$ grau do ensino médio finalizado, ou seja, quase metade.

A educação é um aspecto primordial para o ser humano, além de ser um direito fundamental social como vimos, também visa o pleno desenvolvimento da pessoa, seu preparo para o exercício da cidadania e sua qualificação para o trabalho conforme o art. 205 da Constituição Federal. (BRASIL. CF, 1988).

De acordo com as denotações feitas por Barczack, Vieira e Argondizo (2018, p.93) todos estão "destinados a seguir o 'roteiro' de vida, vinculado aos conceitos capitalistas que dominam nossa região, que consiste em crescer, se alfabetizar, concluir uma graduação [...]". Sendo de suma importância considerar a educação como um fator basilar para conquistar um espaço na sociedade, de se qualificar para o trabalho e progredir cada vez mais durante a vida.

Isso é tão real que os dados apontam que mesmo em rua, as pessoas neste contexto buscam formas de exercer algum tipo de trabalho, mesmo que 47,7\% afirmaram nunca ter tido um emprego formal, apenas 15,7\% pedem dinheiro como principal fonte de renda.

Por fim, e não menos importante, a próxima figura versa sobre fatores extremamente sociais e que limitam a concretização dos direitos dessas pessoas: 


\section{Discriminações sofridas}

\section{Percentual de moradores que sofreram experiências de impedimento de acesso ou realização de atividade}
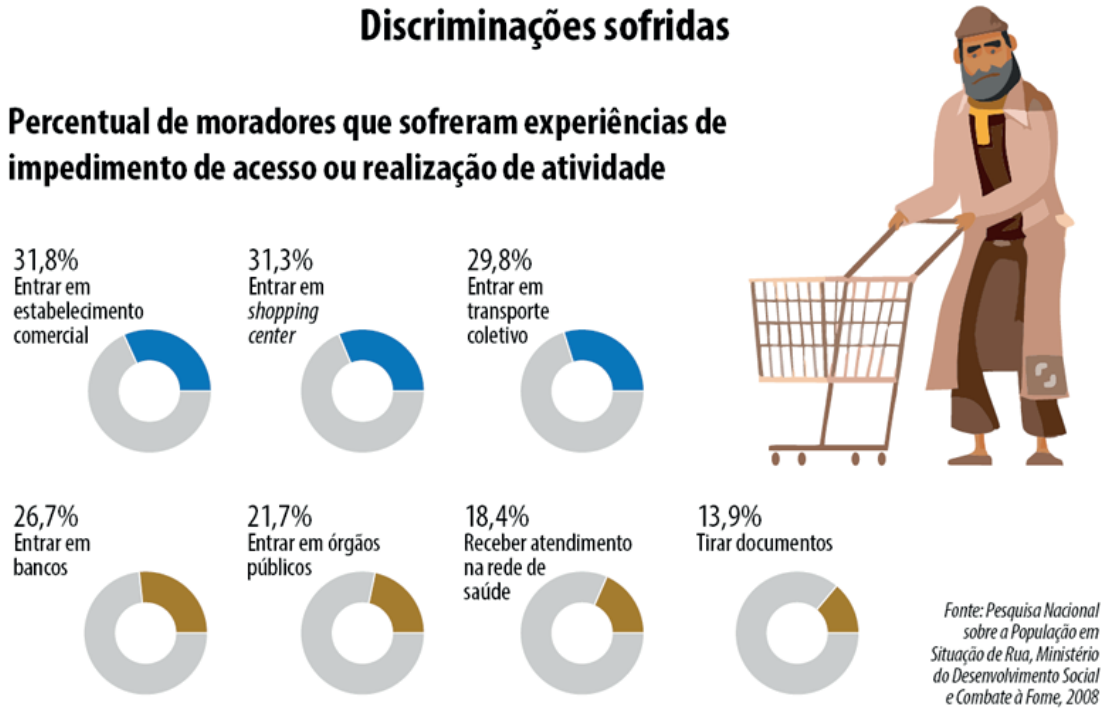

Figura 4 - Discriminações sofridas

Fonte: BRASIL. Senado Federal (2019).

Aqui, a ilustração permite visualizar que não somente pelo Estado, mas, por toda sociedade, a população em situação de rua sofre grande exclusão social, tendo em vista que já foram barradas para entrar em diversos locais públicos, como os estabelecimentos comerciais, que demonstra a maior porcentagem da apresentação da figura, com o percentual de $31,8 \%$, ficando apenas a frente dos impedimentos ocorridos em shopping Center com $31,3 \%$, além de outros locais como transportes coletivo, bancos, órgãos públicos, rede de saúde e locais para tirar documentos.

Vale ainda mencionar que esses impedimentos decorrem em grave ofensa ao artigo $5^{\circ}$, XV da CF que trata sobre o direito de se locomover perante todo o território brasileiro, sendo injustificável qualquer limitação quanto à liberdade de locomoção dos cidadãos.

À luz do exposto, não existe exatidão quanto a quantidade de pessoas em situação de rua no Brasil, sendo que a única pesquisa ampla e detalhada foi feita em 2008, significa dizer há mais de dez anos - tempo suficiente para grandes alterações - demonstrando certa invisibilidade conforme o citado por Diana Bispo (sob supervisão), Cíntia Sasse e Nelson Oliveira, disponibilizado no site do Senado (BRASIL. Senado Federal, 2019).

No mais, as figuras permitem observar que as estimativas apresentadas demonstram na prática o quanto a população de rua possui os seus direitos e garantias fundamentais visivelmente lesados.

\section{As PESSOAS EM SITUAÇÃO DE RUA E O ORDENAMENTO JURÍDICO BRASILEIRO}

As pessoas em situação de rua no ordenamento jurídico brasileiro possuem os mesmos direitos que qualquer outro cidadão. Portanto, mediante o exposto, para que de fato esses direitos sejam validados na vida dessas pessoas é necessário medidas mais específicas.

Os direitos e garantias fundamentais previstos na Constituição Federal de 1988 têm por sua natureza a presunção de eficácia, ou seja, todos de fato existem para serem cumpri- 
dos, quando há certa evasão nestas prerrogativas e de alguma forma for possível verificar que há falhas em sua eficácia social, o Estado precisa buscar formas de fazer valer estes preceitos, para isso existem as políticas públicas.

No tocante a este tema, Valerio de Oliveira Mazzuoli defende que a visão tem sido ampliada em relação as pessoas em situação de rua no que diz respeito ao panorama legislativo. Nisso, discorre:

Hoje em dia, sobretudo no Brasil, o panorama legislativo (felizmente) tem sido outro, ainda que, na prática, o implemento dos comandos normativos seja ainda mais lento e bastante dificultoso. É certo que o poder público já demonstrou ter compreendido que as pessoas em situação de rua são seres humanos que merecem a devida atenção e proteção do Estado, enquanto seres dotados de dignidade e direitos (garantidos também pela ordem internacional de direitos humanos). O desafio, porém, é colocar em prática as políticas públicas voltadas à garantia do bem estar das pessoas em situação de rua, para o fim de retirá-las o quanto antes dessa situação, seguindo modelos de gestão diferenciados dos usualmente empregados (MAZZUOLI, 2018, p. 15-16).

De certa forma, Mazzuoli.(2018) percebe que hoje existe uma sensibilidade maior que busca colocar em prática às políticas públicas existentes para esse determinado grupo de pessoas. Além de afirmar que o Estado tem se preocupado e tentado agir ativamente para que todas as pessoas em situação de rua sejam de fato consideradas alvo de todas as prerrogativas que existem para todo ser humano.

Ao analisarmos as normas constitucionais, não há exceções quanto aos sujeitos alvo de tais prerrogativas. Neste sentido, Valéria Cardin e Nayara B. Pereira Cavalheiro reforçam sobre a positivação dos direitos fundamentais na Constituição:

Os direitos são positivados em um enredo célebre, em momentos históricos e significantes, e quando são previstos na Constituição, se tornam direitos fundamentais que não podem sofrer qualquer restrição, e tão pouco podem ser omitidos pelo Estado, que é o detentor responsável pela efetivação concreta da ordem e justiça social.

Erradicar a pobreza e a marginalização faz parte do rol de objetivos fundamentais da República Federativa do Brasil e está previsto no inciso III do artigo $3^{\circ}$ da Constituição Federal (CARDIN; CAVALHEIRO, 2018, p.277).

Desse modo tais prerrogativas são inegociáveis. Em concordância, Valerio de Oliveira Mazzuoli (2018, p.39) leciona que “o Estado Democrático de Direito é responsável pela eficácia dos direitos fundamentais que visam proporcionar aos cidadãos brasileiros pleno acesso aos seus direitos personalíssimos esculpidos e protegidos pela Carta Magna de 1988".

Porém, é nítido que as pessoas em situação de rua necessitem de um regulamento especial para efetivação de seus direitos. Nesse sentido, temos vigente o Decreto $n^{0} 7.053$ de 2009, que não só trouxe o conceito da população de rua, mas também, buscou desenhar um caminho para concretização dos direitos basilares para esta população. 
Assim sendo, Mazzuoli (2018) analisa o estabelecido no decreto e discorre que por mais que sejam boas iniciativas, ainda falta sustância para que a realidade do exposto seja concreta, pois por mais que sejam iniciativas de suma importância, ainda não há o cumprimento na integralidade do Decreto $n^{0} 7.053 / 2009$, sendo que o poder público no Brasil ainda atua com as antigas práticas, como o isolacionismo, punitivismo, penalização e repressão contra as pessoas em situação de rua.

É de se esperar que além das previsões legais, conforme já explanado, as normas atentem para produzir a eficácia social, pois, nesta questão pode-se observar que o regulamento no decreto apenas preenche pressupostos de eficácia jurídica. Nisto, Mazzuoli alerta para esta questão:

Não obstante alguns avanços no plano legislativo, certo é que a situação
das pessoas em situação de rua ainda é periclitante no Brasil, notada-
mente nos grandes centros urbanos. De fato, não se alcançou ainda o
mínimo ético de proteção dos direitos humanos das pessoas em situação
de rua no Brasil, e não se logrou (até o momento) expurgar as conheci-
das políticas de "higienização" dos grandes centros urbanos, cada vez
mais perniciosas para a efetiva proteção dos direitos dessa categoria de
pessoas (MAZZUOLI, 2018, p.28).

Neste ponto, o professor Mazzuoli aponta em seu estudo que por mais que seja possível verificar certo avanço no plano legislativo, ainda há vitórias a serem conquistadas. Ou seja, ainda precisamos evoluir neste tocante, a fim de que as garantias fundamentais sejam alcançadas por todos.

Ao tratar sobre a evolução dos direitos fundamentais, Mazzuoli (2018) acredita que para ocorrer é necessário um esforço integrado entre o Estado e povo, demonstrando que a própria sociedade se tornar participante daquilo que ainda precisa ser alcançado.

Sendo assim, quando tratamos de pessoas em situação de rua observa-se que os direitos lesados se tratam de matéria excepcionalmente constitucional. A Política Nacional para a População em Situação de Rua existe justamente para realizar àquilo que já temos previsto em nossa Constituição.

Em todo o exposto neste item, verificamos que o ordenamento jurídico não carece de matérias reguladoras de direitos fundamentais, porém conforme doutrina explícita, ainda há um caminho a percorrer para que de fato tudo que está previsto ocorra indistintamente na vida das pessoas submetidas à situação de rua.

\section{O PROBLEMA DA (IN)EFICÁCIA SOCIAL DOS DIREITOS FUNDA- MENTAIS DAS PESSOAS EM SITUAÇÃO DE RUA}

Este tópico tem como objetivo principal demonstrar o problema da (in)eficácia social dos direitos e garantias fundamentais, através de cada um dos itens propostos. Primeiramente, será abordado o papel do Estado na aplicação do direito, bem como a correlação com as pessoas em situação de rua. Após, também serão tratadas questões sobre as políticas públicas pertinentes ao tema, discorrendo seus objetivos e alcances neste contexto 
social. E, por fim, será conceituado o Estado de Coisas Inconstitucional para breve análise e relação aos direitos fundamentais lesados das pessoas em situação de rua.

\section{O PAPEL DO ESTADO NA APLICAÇÃO DO DIREITO}

A formação do Estado está bem consolidada no preâmbulo da nossa Constituição Federal. O doutrinador Alexandre de Moraes, ao discorrer sobre o tema fala da importância do preâmbulo de uma Constituição:

O preâmbulo de uma Constituição pode ser definido como documento de intenções do diploma, e consiste em uma certidão de origem e legitimidade do novo texto e uma proclamação de princípios, demonstrando a ruptura com o ordenamento constitucional anterior e o surgimento jurídico de um novo Estado (MORAES, 2003, p.39).

Portanto, o preâmbulo da Constituição não possui força normativa, mas demonstra valores que introduzem a Carta Magna, revelando princípios e objetivos a ser buscado pelo novo Estado, que conforme o entendimento doutrinário é considerado como o documento de intenções do texto constitucional.

Assim sendo, faremos menção ao que preâmbulo da Constituição vigente estabelece antes de adentrar no papel do Estado na aplicação do direito. Assim encontramos:

Nós, representantes do povo brasileiro, reunidos em Assembléia Nacional Constituinte para instituir um Estado democrático, destinado a assegurar o exercício dos direitos sociais e individuais, a liberdade, a segurança, o bem-estar, o desenvolvimento, a igualdade e a justiça como valores supremos de uma sociedade fraterna, pluralista e sem preconceitos, fundada na harmonia social e comprometida, na ordem interna e internacional, com a solução pacífica das controvérsias, promulgamos, sob a proteção de Deus, a seguinte CONSTITUIÇÃO DA REPÚBLICA FEDERATIVA DO BRASIL (BRASIL. CF, 1988).

Ante o exposto, temos o Estado democrático instituído no Brasil para assegurar o exercício dos direitos elementares, pode-se dizer que é a voz da sociedade, sendo que foi criado por intermédio dos representantes do próprio povo brasileiro.

Tendo em vista a declaração firmada, o Estado existe justamente com um papel muito importante a cumprir, com o intuito de garantir a todos uma vida digna e uma sociedade fraterna. Para tanto, vejamos o que os doutrinadores Reinaldo Dias e Fernanda Matos levantam sobre essa questão:

O Estado é responsável pela ordem, pela justiça e pelo bem como da sociedade. Para tanto, deve legislar (criar e manter em dia uma ordem jurídica eficaz); administrar (prover, através de diversos mecanismos legais e executando os serviços públicos, as necessidades da comunidade) e julgar (resolver pacificamente, de acordo com a lei, os conflitos de interesses que possam surgir e decidir qual é a norma aplicável em caso de dúvida) (DIAS; MATOS, 2012, p.7). 


\section{A (IN)EFICÁCIA SOCIAL DOS DIREITOS E GARANTIAS FUNDAMENTAIS DAS PESSOAS EM SITUAÇÃO DE RUA}

Sendo assim, este fato demonstra que as pessoas permitem que a figura do Estado as represente com a intenção de que todos os direitos sejam resguardados de igual forma para todos.

Portanto, não pode haver restrições quando tratamos dos seres humanos, todos possuem uma vida pela qual deve ser preservada. Nisto, Tereza Rodrigues Vieira e Vanessa Carvalho dos Santos discorrem sobre um princípio fundamental:

Como se sabe, a dignidade da pessoa humana é o princípio de que uma pessoa nunca deve ser tratada como um objeto ou um meio, mas como fim. Merece respeito irrestrito, independentemente do status social. A dignidade é inerente a todo ser humano e deve refletir no sentimento que a pessoa tem de seu próprio valor (VIEIRA; SANTOS, 2018, p. 40)

Por conseguinte, vimos que para o efetivo cumprimento das prerrogativas fundamentais e o objetivo exposto no preâmbulo, o Estado precisa se embasar no princípio da dignidade da pessoa humana. Em consonância, Fabio Konder Comparato ressalta tal importância, assim pontua:

Ora, essa convicção de que todos os seres humanos têm direito a ser igualmente respeitados, pelo simples fato de sua humanidade, nasce vinculada a uma instituição social de capital importância: a lei escrita, como regra geral e uniforme, igualmente aplicável a todos os indivíduos que vivem numa sociedade organizada (COMPARATO, 2008, p.12).

Assim sendo, é importante mencionar que o artigo $1^{\circ}$ da Constituição Federal aborda justamente os fundamentos do Estado Democrático de Direito, e como um deles, temos a dignidade da pessoa humana.

Nessa ótica, conseguimos identificar a importância do papel do Estado no cumprimento dos direitos e garantias fundamentais, estes inerentes da condição do ser humano, sendo, portanto, inegociáveis.

Ao tratar das pessoas em situação de rua, é possível notar que existem direitos fundamentais explicitamente lesados. Neste sentido, é ilusório não atentarmos ao Estado para este fato, pois se trata de uma classe que necessita de medidas efetivas para mudar a realidade vivenciada. Neste aspecto, Vieira e Santos discorre:

O Estado precisa adotar medidas contra a pobreza e também fomentar novos centros de acolhimento municipais com capacidade de treinar e proporcionar cursos para reinserção no mercado do trabalho. As medidas devem ser a curto e médio prazos, pois a demora pode custar vidas (VIEIRA; SANTOS, 2018, p. 43).

Ou seja, neste caso, não basta apenas resolver a situação exterior, a busca pela garantia e o exercício do Estado para a aplicação do direito precisa ir mais além, tendo em vista que estas pessoas estão necessitadas de diversos meios que vão além de uma moradia, por isso, a menção aos direitos e garantias fundamentais. Em consonância, Maria Helena Souza Patto explana: 
Morar com dignidade é mais do que ter um teto sobre a cabeça, não basta que os governantes se limitem a oferecer à população uma casa, pois “apenas quando esta moradia está vinculada aos equipamentos e serviços urbanos é que se criam mínimas para alcançar a cidadania (PATTO, 2010, apud VIEIRA, et al, 2018, p.40).

Mediante o exposto, o papel do Estado está estabelecido pela própria Constituição Federal, desde o preâmbulo é notável o peso que tem a figura do Estado perante a sociedade, se tornando indispensável para realização de todas as prerrogativas previstas, sem que haja exclusão de determinada classe social, mas, como um todo, buscando assim, uma sociedade fraterna.

As políticas públicas

As políticas públicas visam regulamentar os direitos essenciais para que de fato sejam produzidos os seus efeitos na vida de todos, conforme lecionam Dias e Matos "as políticas públicas correspondem a soluções específicas de como manejar assuntos públicos" (2012, p.2). Ainda esclarecem:

As políticas públicas são o resultado da atividade política, requerem várias ações estratégicas destinadas a implementar os objetivos desejados e, por isso, envolvem mais de uma decisão política. Discutir políticas públicas é importante para "entender a maneira pela qual elas atingem a vida cotidiana, o que pode ser feito para melhor formatá-las e quais as possibilidades de se aprimorar sua fiscalização" (DIAS; MATOS, 2012, p.13).

O SEBRAE (Serviço Brasileiro de Apoio às Micro e Pequenas Empresas) de Minas Gerais forneceu um manual que também esclarece a respeito deste assunto de forma mais prática, "as Políticas Públicas são a totalidade de ações, metas e planos que os governos (nacionais, estaduais ou municipais) traçam para alcançar o bem-estar da sociedade e o interesse público" (SEBRAE, 2008, p. 5).

Posto isto, se torna evidente que as políticas públicas versam sobre temas altamente importante para garantir o bem comum. Sendo assim, sempre tratará de direitos que envolvam a coletividade e precisam ser regulamentados para produzirem seus efeitos.

De forma sucinta, é disto que tratam as políticas públicas, a gestão dos problemas e das demandas coletivas através da utilização de metodologias que identificam as prioridades, racionalizando a aplicação de investimentos e utilizando o planejamento como forma de se atingir os objetivos e metas predefinidos (SEBRAE, 2008, p.14).

No entanto, as políticas públicas são uma forma de conduzir ao cumprimento de leis já estabelecidas. Ao fazer a coligação das políticas públicas com as leis existentes, Dias e Matos explicam:

As políticas públicas constituem um meio de concretização dos direitos que estão codificados nas leis de um país. Nesse sentido, a “Constituição não contém políticas públicas, mas direitos cuja efetivação se dá por meio de políticas públicas". Do mesmo modo devem ser consideradas as constituições estaduais e as leis orgânicas municipais, que apresen- 


\section{A (IN)EFICÁCIA SOCIAL DOS DIREITOS E GARANTIAS FUNDAMENTAIS \\ DAS PESSOAS EM SITUAÇÃO DE RUA}

tam disposições jurídicas onde estão codificados direitos de todo tipo (humanos, sociais, ambientais entre outros), e não políticas públicas. Estas têm função explícita de concretizar aqueles direitos junto à comunidade a que se referem: o país todo, os Estados ou as comunidades locais (DIAS; MATOS, 2012, p. 15)

Dessa forma, é certo que para criação desse instituto é necessário um planejamento que irá demandar certo estudo para encontrar métodos e meios para alcançar o objetivo pretendido. Ana Cláudia Niedhardt Capella explica:

O processo de formulação de políticas públicas compreende dois elementos principais: definição da agenda e definição de alternativas. $\mathrm{O}$ primeiro envolve o direcionamento da atenção em torno de questões ou problemas específicos. O segundo, a exploração e o desenho de um plano possível para a ação. Assim, investigar a formulação de políticas consiste em buscar compreender por que alguns assuntos se tornam importantes e acabam concentrando o interesse de vários atores, enquanto outros não. E também por que algumas alternativas são seriamente consideradas, enquanto outras são descartadas (CAPELLA, 2018, p. 9).

Portanto, é através do planejamento mencionado pela autora que serão definidos importante passos das políticas públicas, desde a forma dos métodos criados até a execução propriamente dita.

À vista do exposto, o princípio basilar que define as políticas públicas é o notável planejamento que poderá envolver toda a sociedade civil.

Anteriormente, foi explanado a respeito das pessoas em situação de rua e o ordenamento jurídico, portanto, agora, iremos adentrar especialmente ao que diz respeito às políticas públicas pertinente a este tema.

O especialista Marco Natalino, responsável pela última estimativa realizada pelo IPEA (2016, p.5) demonstrou que a ausência de um número correto em relação às pessoas em situação de rua dificulta a implementação de políticas públicas eficazes.

Ainda, ressalta que o fato de não haver esses dados oficiais demonstra certa indiferença quanto às pessoas contidas nessa situação. Marco Natalino discorre:

O Brasil não conta com dados oficiais sobre a população em situação de rua. Esta ausência prejudica a implementação de políticas públicas voltadas para este contingente e reproduz a invisibilidade social da população de rua no âmbito das políticas sociais (IPEA, 2016, p.5).

Com isso, a estimativa foi feita justamente com a intenção de possibilitar certo anseio para que de fato fossem criadas medidas cabíveis para sanar tal situação. Portanto, nada foi feito, pelo contrário, não houve nem a continuidade das estimativas atualizadas.

Desta forma, é possível verificar que não adianta criar fórmulas se não for começar pelo básico, que é justamente saber quantas pessoas estão encontradas hoje nesta condição.

Destarte, o especialista Marco Natalino (2016) explica que para que haja certa progressão, é necessário que os municípios se interessem em conhecer essas pessoas, enfrentem 
esta realidade para que de fato as políticas públicas sejam eficazes. Assim diz na parte conclusiva da pesquisa feita pelo IPEA:

Há que se ressaltar os limites deste estudo. Ele não é capaz de informar estimativas precisas para cada município. Como é sobre a gestão municipal que recai parcela fundamental das políticas públicas voltadas para esta população, a estimativa aqui apresentada não substitui a necessidade de estimativas mais precisas para que cada município possa planejar suas ações. Recomenda-se que a contagem da população de rua seja incorporada ao Censo Populacional de 2020 para suprir esta carência e que, até esta data, o governo federal incentive as gestões municipais a conhecerem melhor sua população em situação de rua (IPEA, 2016, p.25).

No Brasil, conforme já demonstrado, a Política Nacional para a População em Situação de Rua e seu Comitê Intersetorial de Acompanhamento e Monitoramento, e dá outras providências (BRASIL. Decreto 7.053, 2009), trata especificamente sobre esta questão.

Neste aspecto, também é importante mencionar o Ministério de Desenvolvimento Social e Combate à Fome (MDS), também já citado em capítulos anteriores. Com base na pesquisa, foi possível verificar algumas atividades exercidas pelo MDS para "tornar visível esse segmento populacional ignorado pelas estatísticas nacionais" (BRASIL. MDS, 2009, p.229). Vejamos um dos exemplos:

O MDS trabalha, atualmente, para incorporar as pessoas em situação de rua ao CadÚnico, demonstrando sua determinação em tornar os programas sócias do governo acessíveis ao segmento. Para tanto, foram relativizadas algumas das informações exigidas no ato do cadastramento, como, por exemplo, as referentes à identificação do domicílio familiar do respondente, e investe-se no treinamento e sensibilização das equipes e agentes responsáveis pela abordagem das pessoas em situação de rua. Em uma iniciativa ainda mais inovadora, o MDS e a UNESCO contrataram recentemente, após processo licitatório, o Instituto Pólis para desenvolver junto ao Movimento Nacional de População de Rua um projeto de capacitação e fortalecimento institucional (BRASIL. MDS, 2009, p. 229).

Portanto, embora haja certo esforço por parte do MDS para atender amplamente às pessoas em situação de rua, ainda há que se falar em uma invisibilidade nas estáticas que precisa ser rompida, para assim, poder se falar em medidas dotadas de eficácia, fazendo com que cada Estado, Município e a própria sociedade se atente a esta realidade.

O Estado de Coisas Inconstitucional

O Estado de Coisas Inconstitucional (ECI) foi cunhado pela Corte Constitucional da Colômbia. Trata-se de uma técnica criada em novembro de 1997 a partir da decisão SU-559 com o objetivo de enfrentar casos de graves violações aos direitos fundamentais de forma contínuas e sistemáticas decorrentes de falhas estruturais, envolvendo diferentes entidades estatais (GUIMARÃES, 2017).

O Procurador Jurídico Fábio Marques, definiu em um artigo sobre o Estado das Coisas Inconstitucional da seguinte maneira: 


\section{A (IN)EFICÁCIA SOCIAL DOS DIREITOS E GARANTIAS FUNDAMENTAIS DAS PESSOAS EM SITUAÇÃO DE RUA}

De acordo com a Corte Constitucional Colombiana, que passou a desenvolver essa teoria, desde a Sentencia de Unificación (SU) 559, de 1997, esse Estado de Coisas existe quando um quadro insuportável de violações de direitos fundamentais começam a ocorrer de forma massiva/ generalizada, decorrente da omissão ou comissão de diferentes autoridades públicas, agravado pela inércia reiterada dessas mesmas autoridades, ou seja, a estrutura da ação estatal está com sérios problemas e não consegue modificar a situação tida como inconstitucional (MARQUES, 2016, p.2).

Portanto, mediante os conceitos delineados, o Estado de Coisas Inconstitucional é utilizado para expressar a falência da maneira de agir daqueles que possuem capacidade para tal, mas se encontram totalmente impossibilitados pelas circunstâncias atuais.

Vale ratificar que nem sempre ocorrerá por omissão das autoridades públicas, mas pode ser que haja medidas, porém, se encontram insuficientes para lidar com a grande afronta aos direitos fundamentais, podem-se citar as falhas estruturais em políticas públicas adotadas pelo Estado (GUIMARÃES, 2017). Ou seja, existe certa atuação por parte do Estado, mas não está suprindo as necessidades de fato.

Diante do exposto, não basta que seja apenas a grave violação dos diretos fundamentais, mas, é necessário que ocorra de forma massiva. Assim Carlos Alexandre de Azevedo Campos dispõe:

Quando declara o Estado de Coisas Inconstitucional, a corte afirma existir quadro insuportável de violação massiva de direitos fundamentais, decorrente de atos comissivos e omissivos praticados por diferentes autoridades públicas, agravado pela inércia continuada dessas mesmas autoridades, de modo que apenas transformações estruturais da atuação do Poder Público podem modificar a situação inconstitucional. Ante a gravidade excepcional do quadro, a corte se afirma legitimada a interferir na formulação e implementação de políticas públicas e em alocações de recursos orçamentários e a coordenar as medidas concretas necessárias para superação do estado de inconstitucionalidades (CAMPOS, 2015 apud GUIMARÃES, 2017, p.82)

Sendo assim, é indispensável à atuação do Poder Público ao se deparar com esta questão, pois, é necessário que haja um cuidado especial, demandando políticas públicas pertinentes, disponibilização de recursos orçamentários e uma busca concreta para estabelecer medidas eficazes para sanar o Estado de Coisas Inconstitucional.

No que diz respeito aos requisitos necessários para ser declarado o Estado de Coisas Inconstitucionais, a Corte Constitucional Colombiana (CCC) aborda alguns fatores essenciais. Nisto, Mariana Rezende Guimarães aborda em seu artigo:

De acordo com a Corte Constitucional colombiana, entre os fatores considerados pelo tribunal para definir a existência do estado de coisas inconstitucional, destacam-se: a) a vulneração massiva e generalizada de vários direitos fundamentais que afetam um número significativo de pessoas; b) a prolongada omissão das autoridades no cumprimento de 
suas obrigações para garantir esses direitos; c) a não adoção de medidas legislativas, administrativas ou orçamentárias necessárias para evitar a vulneração dos direitos; d) a existência de um problema social cuja solução demanda a intervenção de várias entidades, requer a adoção de um conjunto complexo e coordenado de ações bem como compromete significativos recursos orçamentários; e) a possibilidade de se lotar o Poder Judiciário com ações repetitivas acerca das mesmas violações de direitos (GUIMARÃES, 2017, p. 83).

Logo, o ECI não pode afrontar apenas uma pessoa, é preciso ser um número significativo de pessoas, além da falta de agir de mais de uma autoridade pública para garantir esses direitos, bem como a existência de um problema social que necessite de uma pluralidade de entidades para chegar à solução.

Conforme anteriormente mencionado, a primeira decisão que reconheceu o ECI foi da Corte Constitucional Colombiana na decisão SU-599 em 06 de novembro de 1997. A Corte Colombiana reconheceu a distribuição desigual do subsídio educativo do Fundo Nacional de Prestações Sociais do Magistério, envolvendo assim, diversos departamentos e municípios do país (GUIMARÃES, 2017).

Logo após, mais precisamente em 28 de abril de 1998, a Corte Constitucional Colombiana reconheceu também o ECI, em relação às condições do sistema penitenciário nacional. No artigo, Mariana Rezende Guimarães sintetiza a decisão da Corte desta forma:

Em sua decisão, a Corte Constitucional determinou a imposição de diversas medidas às entidades estatais, entre as quais se destacam a obrigação de o Instituto Nacional Penitenciário e Carcerário (Inpec), o Departamento Nacional de Planejamento e o Ministério da Justiça elaborarem, em um prazo de três meses, a contar de suas notificações, um plano para a construção e renovação de presídios, de forma a garantir aos presos condições dignas de vida, bem como a obrigação de a Defensoria do Povo e a Procuradoria-Geral da Nação exercerem o monitoramento da implementação (GUIMARÃES, 2017, p. 85).

No Brasil, esse tema surgiu neste mesmo contexto. Foi através da análise da ADPF4347 ajuizada pelo PSOL cujo objetivo era justamente o Supremo Tribunal Federal (STF) reconhecer o Estado de Coisas Inconstitucional do sistema penitenciário brasileiro, devido a condutas comissivas e omissivas dos poderes públicos do Estado no tratamento da questão prisional do País, requerendo assim, a determinação de adoção de medidas para solucionar lesões gravíssimas a preceitos fundamentais da Constituição Federal (GUIMARÃES, 2017).

O STF (BRASIL. STF, 2015b) noticiou o início do julgamento da ADPF 3476, demonstrando a intenção do reconhecimento da violação dos direitos fundamentais da população carcerária e a determinação da adoção de diversas medidas para tratar a questão prisional no país. Assim, o voto do relator da ação, o ministro Marco Aurélio, concedeu parcialmente a cautelar. OSTF dispôs importante fala do ministro sobre o papel do Supremo na ADPF 347:

Para o ministro, o papel do Supremo diante desse quadro é retirar as autoridades públicas do estado de letargia, provocar a formulação de 
novas políticas públicas, aumentar a deliberação política e social sobre a matéria e monitorar o sucesso da implementação das providências escolhidas, assegurando a efetividade prática das soluções propostas. "Ordens flexíveis sob monitoramento previnem a supremacia judicial e, ao mesmo tempo, promovem a integração institucional", concluiu (BRASIL. STF, 2015b).

Desta forma, visualizamos como surgiu o Estado de Coisas Inconstitucional no Brasil, através da ADPF 347 que foi protocolada em 27 de maio de 2015 (BRASIL. STF, 2015a).

No entanto, em decorrência dos apontamentos conceituais a respeito do Estado de Coisas Inconstitucional bem como do breve relato de seu surgimento, e consequente aparição no STF no Brasil, pode-se dizer que há apontamentos que demonstram que a população em situação de rua se enquadra nos fatores levantados no decorrer deste item.

Portanto, ainda não há relatos sobre a tentativa do reconhecimento do Estado de Coisas Inconstitucional no Brasil especificamente neste tema. Mas, para testificar e utilizar como exemplo, vale citar a decisão mais importante da Corte Constitucional da Colômbia narrada pela Analista Processual do Ministério Público da União Mariana Rezende Guimarães:

Contudo, a decisão mais importante da Corte Constitucional da Colômbia relativa ao reconhecimento do estado de coisas inconstitucional foi a sentença T-025, de 22 de janeiro de 2004, na qual a Corte lidou com o problema dos desplazados (deslocados).

Nessa decisão, a Corte Constitucional considerou que as políticas públicas então existentes eram incapazes de superar o estado de coisa inconstitucional em que estavam situados os deslocados, tanto em razão da insuficiência dos recursos públicos destinados aos programas quanto em razão das capacidades das instituições estatais envolvidas (GUIMARÃES, 2017).

Embora sejam situações derivadas de contextos diferentes, por se tratar de pessoas em extrema vulnerabilidade social e pelas falhas estruturais em políticas públicas aplicadas pelo Estado conforme visto no item anterior, as pessoas em situação de rua no Brasil e as pessoas deslocadas na Colômbia possuem certa ligação

Portanto, tendo em vista as informações apresentadas, há que se levantar a possível arguição de um problema de Estado de Coisas Inconstitucional, sendo que aqueles que deveriam ao menos contribuir para minimizar a situação evidenciam a falência de suas ações.

\section{CONSIDERAÇÕES FINAIS}

A Constituição Federal brasileira de 1988, como norma suprema da nossa organização governamental, estabelece princípios e diretrizes que emergem todo o ordenamento jurídico. Sendo assim, o objetivo do estudo consistiu justamente em analisar a eficácia social das normas de direitos e garantias fundamentais que nela se encontram, especialmente em relação às pessoas em situação de rua.

Logo, foi possível verificar que por sua natureza normativa, esses direitos são dotados de eficácia jurídica e possuem aplicabilidade imediata, além disso, são inegociáveis e pertencentes a todas as pessoas, e isto permite enaltecer a seriedade do tema escolhido, dado que quando não concretizados, afronta diretamente a própria condição de ser humano. 
No Brasil, as normas de direitos fundamentais são bem estruturadas, pois contém todos os elementos normativos essenciais para produzir os seus efeitos, ou seja, são juridicamente eficazes, porém, é notório que no contexto social ainda existem muitas pessoas à margem do que as Leis, Tratados e a própria Constituição Federal prevê. Para compreender melhor, ao ir de encontro com a realidade das ruas vemos nitidamente a distância entre as normas propriamente ditas e os efeitos sociais produzidos.

Sobretudo, vimos que as pessoas em situação de rua são aquelas que além de não terem moradia fixa, utilizam meios de sobrevivência que colocam em risco sua saúde, integridade e a própria vida. Os dados apontam que antes de adentrar a realidade das ruas, muitos nunca tiveram um emprego formal, e boa parte não teve ao menos acesso à educação de forma íntegra, e esses também são preceitos fundamentais estabelecidos em nossa Carta Magna.

Diante disso, o presente estudo permitiu observar que a problemática vai muito além do que resulta nas calçadas, visto que não é somente a questão da ausência de moradia, mas, existem outros direitos que precisam ser reparados em sua essência para que a realidade vivenciada seja transformada e evitada, e isto é algo que não pode ser negligenciado pelo Poder Público.

Como se pôde notar no desenvolvimento do presente estudo, o Estado é omisso em acompanhar tal questão social, pois no mínimo, deveríamos contar com dados atualizados neste tema. Então, considerando que a última estimativa foi feita em 2016, percebe-se que o Estado não demonstra interesse em levantar a quantia de pessoas inseridas neste contexto, mesmo possuindo o dever de prestar assistência devida para garantia de direitos.

Pois bem, de um lado há normas e garantias estabelecidas em lei e do outro o clamor tácito de pessoas que sequer possuem o básico para viver. Posto isto, se torna necessário conhecer e buscar medidas cabíveis para que toda população em situação de rua seja alcançada e amparada como qualquer outro cidadão.

No tocante à ineficácia social dos direitos e garantias fundamentais, ficou nítida que ocorre por ausência de políticas públicas eficazes, essas que estão limitadas por não haver a cautela necessária do Estado, que para tanto, precisa se movimentar para fazer valer os preceitos estabelecidos.

Portanto, convém denotar que não só o Estado, mas, muitas vezes, este fato é ignorado por grande parte da sociedade. Nisso, o estudo proporcionou uma visão ampla a respeito da contextualização das pessoas em situação de rua, mostrando que a indiferença é obra de toda sociedade, pois, infelizmente tem se tornado algo cada vez mais corriqueiro no dia a dia, fazendo parecer que isso é "normal".

Todavia, não é "normal" mais de 100 mil pessoas desamparadas pelo mínimo existencial, ainda mais, não é "normal" tamanha indiferença a ponto de tornar-se essa realidade invisível nas estatísticas. Não é "normal" se deparar com normas tão esclarecedoras e condizentes para destravar e garantir a todos uma boa vida, jogadas no chão ao lado dessas pessoas. Não podemos deturpar a nossa visão e enxergar tal fato como "normal". Não dá para vivenciar este tipo de situação e encarar como algo "normal", pois estamos tratando de seres humanos e não qualquer objeto descartável: cada vida na rua representa uma história, sonhos roubados e esperança desfalecida por algum motivo.

De nada adianta textos bem regulamentados que fazem nossos olhos brilharem se a realidade está pendendo para outra direção. É necessário que a busca por meios de minimizar essa situação seja incessante! 
Muitas vezes o agir pode se dar através de sementes de valorização, e isso pode começar com o simples fato de torná-las visíveis, pois a exclusão e tamanha indiferença faz com as estimativas se tornem permanentes e aumente ainda mais. Portanto, a princípio, é necessário que cada município, se abasteça de interesse em conhecer esta população e em fazer valer ou até mesmo criar políticas públicas eficazes para amenizar a quantia de direitos lesados e devolver a estas pessoas a chance de serem enxergadas como pessoas.

Infere-se que há falência nas tentativas de traçar um caminho para sanar tal questão social. A significativa quantidade de pessoas lesadas, as graves violações aos direitos fundamentais e as omissões de diversos órgãos em meio à realidade proposta demonstram o estado de coisas inconstitucional sendo que aqueles que deveriam ao menos contribuir para minimizar a situação evidenciam a falência de suas ações, tornando necessário um cuidado especial, que irá demandar políticas públicas pertinentes, disponibilização de recursos orçamentários e uma busca concreta para estabelecer medidas eficazes para tanto.

Em suma, mediante todo o exposto, notamos que há certo preconceito de todos os lados em relação à população de rua, até porque muitos julgam que as pessoas neste cenário são simplesmente culpadas e estão ali porque não fazem nada para mudar. Portanto, quando nos colocamos a disposição para entendermos esse fenômeno, verificamos que não é bem assim. Torna-se fácil culpar quando ninguém sabe como chegam e não se importam como é a trajetória para conseguir sair!

É recorrente se importarem em limpar mais a rua do que com as pessoas que ali estão. Elas podem incomodar como o lixo, mas deveriam muito mais nos incomodar por serem tratadas como um "bicho". Ouvimos dizer que alimentar as pessoas em situação de rua é um incentivo para ali continuarem, mas quando foi que matar de fome se tornou um motivo para elas saírem? A verdade é que precisamos ir além do que nossos olhos podem alcançar quando nos deparamos com os sujeitos em situação de rua. Não podemos generalizar, mas podemos cercar a fim de que todos que busquem uma oportunidade encontrem, e para isso, é imprescindível a atuação do Poder Público.

À luz do exposto, é de grande valia para sociedade como um todo, buscar a concretização desses direitos e garantias que são embasados em princípios constitucionais irrepreensíveis, a fim de que a igualdade e a justiça não sejam apenas um brasão do Direito, afinal, todos possuem o mesmo valor como seres humanos.

\section{REFERENCIAS}

BARCZAK, N. N; VIEIRA, T. R; ARGONDIZO, L. F. C. Pessoa em situação de rua: aspectos sociais. In: VIEIRA, T. R. et al. Pessoas em situação de rua: Invisibilidade, preconceitos e direitos. 1. ed. Brasília, DF: Zakarewicz Editora, 2018.

BARROSO, Luís Roberto. O direito constitucional e a efetividade de suas normas: limites e possibilidades da Constituição brasileira. 4. ed. Rio de Janeiro: Renovar, 2000.

BRASIL. Constituição Federal (CF). Constituição da República Federativa do Brasil de 1988. Disponível em http://www.planalto.gov.br/ccivil_03/constituicao/constituicao. htm. Acesso em: 10 mai. 2019. 
. Decreto $n^{0} 7.053$ de 23 de dezembro de 2009. Disponível em: http:/ / www.planalto. gov.br/ccivil_03/_ato2007-2010/2009/decreto/d7053.htm. Acesso em: 27 mai. 2019. . GOVERNO DO BRASIL. Constituição Federal. 2009. Disponível em: http:/ /www. brasil.gov.br/governo/2010/01/constituicao. Acesso em: 10 mai. 2019.

. Ministério do Desenvolvimento Social e Combate à Fome (MDS). Rua: aprendendo a contar: Pesquisa nacional sobre a população em situação de rua. Brasília - DF: MDS, 2009. Fundação Cultural Palmares: México cria conselho nacional contra a discriminação, 2006. Disponível em: http:/ / www.palmares.gov.br/ ?p=1584. Acesso em 06 jun. 2019. . Supremo Tribunal Federal (STF). Consulta processual ADPF 347, 2015a. Disponível em: http:/ / portal.stf.jus.br/processos / detalhe.asp?incidente $=4783560$. Acesso em 27 mai. 2019.

. Supremo Tribunal Federal (STF). Notícias STF: STF inicia julgamento de ação que pede providências para crise prisional. 2015b. Disponível em: http:/ /www.stf.jus.br/portal/cms/verNoticiaDetalhe.asp?idConteudo=298600. Acesso em 27 mai. 2019.

BRASÍLIA. Marco Antônio Carvalho Natalino. Instituto de Pesquisa Econômica Aplicada. Texto para discussão: Estimativa da população em situação de rua no Brasil. Rio de Janeiro: Ipea, 2016.

CAPELA, Ana Cláudia Niedhardt. Formulação de Políticas Públicas. 1. ed. Brasília: Enap, 2018.

CARDIN, V.S.G; CAVALHEIRO, N. B. P. Travestis em situação de rua e a garantia de moradia como direito fundamental. In: VIEIRA, T. R. et al. Pessoas em situação de rua: Invisibilidade, preconceitos e direitos. 1. ed. Brasília, DF: Zakarewicz Editora, 2018.

COMPARATO, Fábio Konder. A afirmação histórica dos direitos humanos.6. ed. São Paulo: Saraiva, 2008.

COSTA, C.S; VIEIRA, T. R. O idoso em situação de rua. In: VIEIRA, T. R. et al. Pessoas em situação de rua: Invisibilidade, preconceitos e direitos. 1. ed. Brasília, DF: Zakarewicz Editora, 2018.

DIAS R., MATOS F., Políticas Públicas: Princípios, Propósitos E Processos. 1. ed. São Paulo: Editora Atlas, 2012.

FERRARI, Regina Maria Macedo Nery. Direito constitucional. São Paulo: Editora Revista dos Tribunais, 2011.

. Normas constitucionais programáticas: normatividade, operatividade e efetividade. São Paulo: Editora Revista dos Tribunais, 2001.

FERREIRA FILHO, Manoel Gonçalves. Curso de Direito Constitucional. 37. ed. São Paulo: Saraiva, 2011.

. Direitos humanos fundamentais. 14. ed. São Paulo: Saraiva, 2012.

GUIMARÃES, Mariana Rezende. O estado de coisas inconstitucional: a perspectiva de atuação do Supremo Tribunal Federal a partir da experiência da Corte Constitucional colombiana. 2017. Disponível em: http://escola.mpu.mp.br/publicacoes/boletim-cientifico/ edicoes-do-boletim/boletim- cientifico-n-49-janeiro-junho-2017/o-estado-de-coisas-inconstitucional-a-perspectiva- de-atuacao-do-supremo-tribunal-federal-a-partir-da-experiencia-da-corte- constitucional-colombiana. Acesso em: 27 mai. 2019. 
MARQUES, Fabio. O que se entende por Estado de Coisas Inconstitucional? Disponível em: https:/ / fabiomarques2006.jusbrasil.com.br/artigos/296134766/o-que- se-entende-por-estado-de-coisas-inconstitucional. 2016. Acesso em: 27 mai. 2019.

MAZZUOLI, Valerio de Oliveira. Problema dos Direitos Humanos das Pessoas em Situação de Rua no Brasil. In: VIEIRA, T. R. et al. Pessoas em situação de rua: Invisibilidade, preconceitos e direitos. 1. ed. Brasília, DF: Zakarewicz Editora, 2018.

MORAES, Alexandre de. Direito constitucional. 13. ed. São Paulo: Atlas, 2003.

SARLET, Ingo Wolfgang. A eficácia dos direitos fundamentais: uma teoria geral dos direitos fundamentais na perspectiva constitucional. 10. ed. Porto Alegre: Livraria do Advogado, 2009.

SEBRAE/MG. Políticas Públicas: conceitos e práticas. 1. ed. Belo Horizonte: Sebrae/MG, 2008.

SILVA, José Afonso da. Aplicabilidade das normas constitucionais. 3. ed. São Paulo: Malheiros Editores Ltda, 1999.

VIEIRA, T. R. et al. Pessoas em situação de rua: Invisibilidade, preconceitos e direitos. 1. ed. Brasília, DF: Zakarewicz Editora, 2018.

VIEIRA, T. R; SANTOS, V. C. Bioética e direito: Vulnerabilidade da Pessoa em situação de rua. Será que alguém se importa? In: VIEIRA, T. R. et al. Pessoas em situação de rua: Invisibilidade, preconceitos e direitos. 1. ed. Brasília, DF: Zakarewicz Editora, 2018. 